\title{
Effects of Staffing Policies on Public Secondary School Teachers' Distribution in Homa-Bay County, Kenya
}

\author{
Vitalis Oliech Amolo \\ Adega Mixed Secondary School, Box 60, Kadongo, Kenya \\ Dr. Jack Odongo Ajowi \\ Department of Curriculum and Education Management, School of Education \\ Jaramogi Oginga Odinga University of Science and Technology, Box 210, Bondo, Kenya

\section{Dr. Pamela Raburu} \\ Department of Psychology and Educational Foundations, Dean School of Education \\ Jaramogi Oginga Odinga University of Science and Technology, Box 210, Bondo, Kenya
}

The success of any policy lies in its effective implementation and staffing policies for teachers are meant to ensure sufficient teaching force that is equitably distributed in all public schools. Despite various staffing policies put by Ministry of Education (MOE) and Teachers Service Commission (TSC), in Kenya many schools are still understaffed and the available teachers are not equitably distributed. Homa-Bay County is currently understaffed by 1044 teachers spread across the six Sub-Counties despite regularly recruiting teachers as per the TSC policies. The deficit and inequitable distribution of teacher is therefore not due to non-employment but rather, due to implementation of staffing policies. The existence of deficit and inequitable distribution of teachers despite regular recruitment suggest a problem in the staffing policies and its implementation, and therefore warranted this research. The purpose of the study was to investigate the effects of teachers staffing policies on public secondary school teacher distribution in Homa-Bay County. The objectives of the study were to; examine the staffing policies for teachers in Kenya, determine the extent of implementation of the policies in Homa-Bay County, examine challenges influencing implementation of staffing policies, and to assess various measures being put in place to mitigate the situation. A conceptual framework was developed focusing on factors influencing implementation of staffing policies. The study employed ex-post facto research design with a study population of 283 head teachers of public secondary schools, 2318 teachers, 6 Sub-County Directors of Education and 1 TSC County Director of Education. Stratified sampling technique was used to select $30 \%$ of teachers and head teachers from the Sub Counties owing to the large number. Saturated sampling method was also used to sample the Sub-County and County TSC Director of Education. Questionnaires, interview schedule and document analysis guide formed instruments for data collection. Face and content Validity of instruments was ensured by experts in the Department of Educational Curriculum and Management of Jaramogi Oginga Odinga University of Science and Technology. Reliability of instruments was established through a pilot study in 10\% of the schools outside the sample and weaknesses noted corrected before preparing the final copy. Quantitative data were analyzed using descriptive statistics in the form of frequency counts, mean and percentages. Qualitative data were transcribed and coded into themes and sub themes and analyzed using thematic analysis as they emerge based on research objectives. The finding of the study is useful in redesigning staffing policies under the new constitution of devolution and it also outline various considerations to be made during implementation of policies. The study has also contributed to knowledge on teacher management, policy formulation and implementation

Keywords : Staffing Policies and Teachers' Distribution.

\section{BACKGROUND TO THE STUDY}

The success or failure of any system or programme of an organization greatly depend on its human resource that is staffing. Staffing is the process by which organizations ensure that they have the number and type of people needed to create, produce and deliver the organization's product and services (Hellningel, Jackson, Sloam \& Stande, 2002). Okumbe (1999) view staffing as bringing in and training the staff and maintaining favorable condition of work. Shaun and Alfred (2002) defines staffing as the task of finding people who either posses or have potentials to develop the knowledge or 
skills and attitude that will enable an organization to carry out the task necessary for the achievement of aims and objective. Whatever the definition, Roger, Winston, Don, and Greamer (1997) assert that an excellent staffing program begins with hiring the right people and placing them in position with responsibility that allow them to maximize their skills, knowledge and talent. Different organizations have set up policies on staffing. These policies vary from one organization to another. Since organizations are never static, staffing policies are likely to change from time to time to address emerging trends. Schools require adequate staff to enable it achieve its objective. The staff should be adequate in number and in qualification to ensure stability and continuity. The government is committed to staffing all schools according to the CBE and staffing policies but has not been able to achieve this goal. Staffing of schools with adequate teachers has been a challenge to the government not only to Kenya but also in other parts of the world. Other countries have put in place staffing policies and measures to deal with various staffing challenges.

In USA, American constitution established a federal state yet with limited powers including management of education (Leinwand, 1992). Education falls under the primary authority of the states. Control of education in each state is delegated to local school districts. All states have an appointed or elected state superintendent of schools or agency. Local school districts have vast powers including hiring and firing staff in schools. Staff shortages exist and in order to cope with rising enrollment, Americans use technology to supplement especially in subjects like math, and sciences (Leinwand, 1992). America introduced Teach for America (TFA) policies which attract the best, brightest and talented students to be recruited to energize school improvements (Mikunde \& Wise, 2008). Each state makes its own rules concerning who can be certified and what they can be certified to teach.

Similarly in Britain staffing policies vary from one school to another depending on the type and nature of schools. Schools in Britain are categorized depending on the sponsor; Community schools, Voluntary controlled schools, Voluntary Aided or foundation or Trust.(England Regulation, 2009). Staffing is therefore decentralized and delegated to various bodies and boards like Local authority Council, the governing council and Diocesan council. These authorities set staffing policies in respective schools in line with the constitution.

In Swaziland, staffing of teachers is done by the Teaching Service Commission (TSC) which was established through the teaching service Act of 1982 and its regulation of 1983. Teachers Service Commission is in charge of teacher employment, recruitment, confirmation, promotion, appointment, transfer, discipline and termination of employment.

In Kenya, staffing policies have evolved from the time the first school was set up by the missionaries and has changed from time to time during the colonial and post colonial era. At independence, recruitment of teachers had been supply driven. This was basically to replace the expatriate that were leaving when Kenya attained independence and to carter for increased student enrollment. Under this system, graduates were posted as soon as they graduated from colleges (Sifuna \& Otiende 2006). This system changed in 1997 with the government policy on staff rationalization, retrenchment and freeze of employment. In 2001 teacher recruitment became decentralized. With the elevation of TSC to a constitutional body from May (2012), TSC has set up policies on transfers which among other things include availability of vacancy, promotion after a successful interview or on medical ground (TSC, 2005).Teacher recruited under this system are also expected to serve in the same station for at least five years (Sogomo, 2002).

Despite all these policies in place, teacher shortage is still a problem in many parts of Kenya including Homa-Bay County. Homa-Bay has been receiving teachers during recruitment but the problem of staffing still persist with some schools having as low as one TSC teacher instead of a CBE requirement of 9 teachers. Apart from teachers not being enough, teachers are not equitably distributed. Total teacher turnover is fairly evenly split between two components attrition (those leaving the service altogether) migration (those who move to teaching jobs in other schools).Currently teacher shortage in Homa-Bay. Teacher deficit raises questions about the staffing policies and its' implementation in Homa-Bay County and therefore understanding the effect of staffing policies on public secondary school teachers distribution in Homa-Bay County is important in developing strategies to eradicate disparity and this therefore justified the present research.

The Kenya government has been committed to staffing of all public schools with sufficient teachers as per the curriculum based establishment and returns. Homa-Bay County has been recruiting teachers from time to time in line with TSC staffing policy. Staffing policies defines issues on employment, 
transfers and deployment. Staff balancing and rationalization has also been done on top of restrictive policies to teachers to address staff turnover (Sogomo, 2002). The Kenya Government has been keen on reducing teacher turnover by creating incentives like hardship allowances in some part of HomaBay County. Despite all these measures, there still exist deficits and disparities. The trend is worsening with the introduction of subsidized secondary school education. The fact that these disparities and deficits exist suggest the existence of certain factors (constraints) influencing the implementation of these staffing policies. This study therefore examined the effect of staffing policies on public secondary school teacher distribution in Homa-Bay County.

The purpose of the study was to examine the effects of staffing policies on public secondary school teacher distribution in Homa-Bay County.

The specific objective of the study were to:

1. Examine the staffing policies in Kenya's public secondary schools.

2. To determine the process of implementation of the staffing policies.

The research was guided by the following questions;

1. What are the staffing policies in Kenya public secondary schools?

2. How are the staffing policies implemented in Homa-Bay County?

The study was guided by the following assumptions:

1. Staffing policies should ensure that there is equitable distribution of Teachers in secondary schools.

2. During recruitment, transfers and balancing of teachers, policies are strictly followed.

3. Schools put in their requests for teachers in good time.

4. Teachers recruited by TSC can serve in any part of the country

Although staffing policies have been in existence since independence, this study covered the period between 2009 and 2013. The five years were enough to assess a full cohort of secondary school circle with staffing problems. The period also marked a full circle of increased enrollment after implementation of free primary education and subsidized secondary education. The study covered movement of teachers to other schools and other sectors.

The study is significant to TSC/MOE in redesigning staffing polices under the new constitution and devolution and has outlined considerations to be made during implementation of policies. The study has also contributed knowledge on teacher management in terms of policy formulation and implementation.

\section{RESEARCH METHODOLOGY}

A research design is a detailed plan on how a research study will be conducted from data collection to analysis (Babbie, 2007) Kombo and Delno (2006) defines it as a framework that explains how data will be collected and analyzed in an investigation. It therefore provides the most valid and accurate answers to research questions (Asqeith, 2008).

The present research employed Ex-Post Facto research design which is defined as systematic inquiry in which the researcher does not have direct control of the independent variables because their manifestations have already occurred or because they are inherently not manipulatable (Kerlinger, 2002). Inferences in this design are made without direct intervention of independent and dependent variables. In Ex post facto research design, the researcher takes the effects (or dependable variables) and examines the data retrospectively to establish cause relationship and associations. It's primary advantage is that a great amount of data can be gathered within a short time (Creswell, 2014).Ex post factor research design is useful when it is impossible, impractical or costly or unethical to conduct an experiment (Cohen,2007).It is useful when it is not possible to select, control and manipulate the factors necessary to study cause and effects relationship directly. Ex post facto design is necessary when the control of all variables may be unrealistic or artificial (Anika, 2015) Further it is relevant where the independent variables lies outside the researcher's control and where simple cause and effects relationship is being explored. The design can masquerade as a genuine experiment making it more reliable (Hammers \& Badia, 2005). 
Although it Ex post facto have strengths, its' weaknesses also exist in that one cannot know for certain whether the causative factors have been included or even identified (Lanip,2015).It may also be that no single factor is the cause (Cohen, Mannion \&Morrison, 2007) and particular outcomes may result from different causes or different occasions in Homa-Bay County staff shortage and in equitable distribution is a reality and a factor of staffing policy and therefore the researcher looked at the impact of these policies. Ex post Facto design was appropriate in this study to explore teachers, head teachers and staffing officer's opinion and knowledge on staffing policies, implementation of the policies and effects on distribution of public secondary school teachers owing to the vastness of the County, amount of data to be collected and the fact that certain variables were not easy to manipulate. It was also found to be relevant because the event had already occurred over a long period of time.

The study was conducted in Homa-Bay County which lies between longitude $0^{0} 15$ and $0^{\circ} 45$ south and $34^{0} 25$ East and $35^{\circ} 0^{\circ}$ East. The County population as per 2009 census is 363,794 and population density is 303 per Square kilometer. Out of the population, 28,361 live in urban centers and the rest in rural setups. Sizeable area of the County is covered by water (Lake Victoria). The County boarders Migori County to the South, Siaya County to the North, Kisumu County to the east. Economic activities carried out are varied ranging from farming, agriculture, fishing, quarrying and trade mostly for subsistence. Administratively, Homa-Bay County has six Sub Counties with eight constituencies. Academic performance have been affected by various factors among them being staffing policies. Homa-Bay County fitted this study because of it's vast nature with different geographical characteristics. It has island and mainland. Staffing situation vary from school to school, region to region. Different regions have varied level of economic and social background. The County have diverse category of school namely; boys, girls, mixed, day and boarding, urban are rural schools (Otieno \&Offula, 2009). In total Homa-Bay County has 283 public schools.

Study population refers to a group of individuals or persons or objects from which sample are taken for measurement (Ensinga, Tegrotenhuis \& Pelze, 2012). It refers to all members of any well defined class of people or entire group of participants that particular study is interested in (Morgan, 2006). It is also known as well defined collection of individuals known to have similar characteristics. It refers to the entire group of individuals or objects which a researcher is interested in generalizing the conclusion (https://explorable.com/reseach). The population of the study consisted of 283 head teacher of public secondary schools, 2318 teachers, six sub County staffing officers and 1 TSC County Director.

Sample size refers to a portion drawn from a population intended to lead to statistical estimates of the attributes of the whole population (Manuay, 2010).It is a representative of a whole (Mac Neil \& Chapman, 2005) a selected group to act as a specimen for test or tria (1 Bartlect, Kotrlike \& Higgins, 2001). Sample size determination aid researcher in choosing the number of observation to include in a statistical sample (Kombo \& Delno, 2006). In the present study, the researcher used Stratified random sampling technique (Mason, 2002) as it fit with quantitative research to sample $30 \%$ of the teachers and head teachers owing to the large population (Bell 2003). It is a criterion based sampling meaning that the participant are selected because they have particular knowledge pertaining to the question to be explored (Patton, 2003). Stratified sampling was to enable all the six sub counties to have adequate representation in terms of teachers and head teachers. The percentage which is $1 / 3$ of the population is considered to be flexible, efficient, reliable and representative enough (Kothari, 2004). Stratified random sampling was used to select 85 head teachers, and 696 teachers. This procedure is relevant for the study because it helps reduce chance variation between sample and the population represented by capturing key population characteristics. (Grinnel, 2010). Saturated sampling method was also used to select 6 sub County staffing officer and TSC County director due to their small number and the significant role they play in staffing (Mason, 2010).

Instrumentation refers to data collection tools (Lucas, 2013). Data was collected using questionnaires, interview schedule and document analysis. Questionnaires were used to collect quantitative data from teachers and head teachers. Questionnaires obtained facts and opinions about phenomenon from people who are informed on a particular issue (Babbie, 2007). Questionnaire guaranteed Confidentiality (Cresswel, 2014) and enabled researcher to reach a large group within a short time. The researcher obtained primary information by directly issuing questionnaires to teachers and head teachers. 
Interviews schedule and Focus Group discussions were used to collect qualitative data. Interviews is a form of qualitative research method which involves the construction and reconstruction of knowledge (Mason, 2002). In addition it a flexible interaction and generative tool that explore meaning and language in depth (Silveman, 2001).Interviews is a qualitative tool which allow researcher and participant some freedom to negotiate their own meaning and further allowing the researcher to explore in depth interesting issues through conversation(Cohen, Manion \& Morrison,2007). The approach is viewed as suitable for reaching an understanding of meaning as individual attributes to some aspects of personal experience and the sense of self (Punch 2005).

Some dangers are however associated with interviews (Wengraf, 2001) in particular the danger of assuming that the information gathered during an interview can simply be extracted and groted, it is also time consuming in nature and the possibility of objectivity by the researcher is sometimes doubted (Punch,2005).Interviews are subjected to bias casting doubt on the reliability of the data (Mcneil \& Chapman, 2005). the recall of events in interviews is seen as a major setback (Fontana \& Frey,2003) This study found interviews suitable for the study despite its limitation since it was flexible and provided opportunity to observe the subject in situation in which they are responding. Interviews further brought immediate feedback. It was used in collecting information from headteachers, Sub County staffing officers and County TSC director.

Pilot test of research instruments was conducted for this study in selected schools in Homabay County. Stratified sampling method was used to generate 6 public schools, one from each sub-County. From the six schools, 12 headteachers and 63 teachers were selected for piloting through stratified sampling method. This was in line with Bille,(2010) who noted that $9 \%$ of the total sample was adequate for pilot testing. Questionnaires were administered to the Teachers and Head teachers and interpretation of responses, alternatives and vagueness was carried out. Order of response alternatives was changed for questions with normal scales to assess the validity and reliability. Respondents' choices were evaluated for appropriateness. The researcher verified if the question were comprehended in the same way by the respondents. Average time taken to complete the questionnaire were noted and the overall test results discussed with fellow researchers. Adjustments were made prior to the production of the final instrument.

On interview, the researcher had one to one discussion with the sample headteacher and the subCounty staffing officer together with TSC County director as preconceived in the appendices. Responses during the interview were tape recorded as given by respondents. Quantitative data was collected using questionnaires from 85 head teachers and 696 teachers while qualitative data were collected from 21 headteachers, 6 sub County staffing officers and 1 TSC County director.

The Head teachers questionnaire consisting of section A and B was used. Section A collected general information about the head teacher and the school. Section B with Likert like items, with both open and close ended questions were used to collect information on staffing policies and its effects on the distribution of teachers, factors affecting effective implementation of staffing policies inHoma-Bay County and strategies being put in place. These questionnaire had a response format of 5 point scale; strongly Agree, Agree, Undecided, Disagree and Strongly Disagree.

Validity is defined as the accuracy and meaningless of inferences which are based on research results (Creswell, 2014)or whether a measuring device measure what it purport to measure (Kombo \& Delno, 2006). It is vital for a test to be valid in order for the result to be accurately applied and interpreted (Oso \& Onen 2005) Face validity (the degree to which an instrument measure the characteristics or traits of interest) and content validity (the degree to which the instrument fully measure the construct of interest) of the study instrument was ensured .(Moskal \& Leydens, 2000). Validity was ascertained by making clear statements on staffing policies and it's effects on teacher distribution in Homa-Bay County. The instruments were then presented to experts from the Department of Educational Management and Foundation at Bondo University who examined the content. Their input were used in revising the instruments before preparing the final copies.

Reliability refers to the consistency of a measuring tool or the degree to which that instrument produces equivalent result for repeated trials (Eisinga, TeGrotenhius \&Pelzer 2014). To enhance reliability, two different types of instruments were used that is, questionnaires for teachers and head teachers and interviews for Sub-County and County TSC directors of education. A pilot study was conducted in 6 (one school in each Sub County) schools outside the study sample. Piloting help 
researcher to identify areas and question that were not well understood for modification which includes terms that were difficult. Inconsistencies, deficiencies and weaknesses noted in the responses from the pilot study were corrected in the final document before administration (Polit, Beck, \& Hungler, 2001).

Quantitative data collected using questionnaires on Staffing Policies and it's effects on Teacher Distribution in Homa-Bay County was analyzed using descriptive and inferential statistics in the form of frequency counts mean and percentages using SPSS version 11.5 and presented in tables according to school, student, individual teacher and administrative factors. Inferential statistics enabled the researcher to present data obtained in statistical format so as to facilitate identification of important information derived from research questions that made data analysis more meaningful. Quantitative analysis help in estimating the probability of a significant difference between parameters of two or more population under study.(Morgan, 2007)Data from staffing policies, its' implementation, factors influencing implementation and strategies being put in place were entered, coded and analyzed by means of statistical package for social sciences (SPSS).

Qualitative data from interviews and open ended question with Sub-County and County TSC director of Education were transcribed, coded as was in Raburu,(2015;2011)and analyzed using thematic Analysis according to Braun and Clarke,2006). Thematic analysis is a method of identifying, analyzing and reporting patterns (themes) within Data (Braun \&Clarke, 2006). It minimally organizes and describe data set in details. It goes further than this to interpret various aspects of research topic.(Braun \&Clarke, 2006). Qualitative data analysis involve such processes as data reduction, display, conclusion and verification (Denzin \&Lincoln, 2011).It involved developing a detailed description of each case and situating the case with the context.

In Research generally, fundamental ethical issues arise from the problems scientist investigate and the method they use. These problems range from confidentiality, cultural diversity, disclosure, informed consent, risk assessment or the impact the research would have on the lives of participants and problem of potential deception and negligence during research (Denzin \& Lincoln 2011, Oso $\&$ Onen,2011). Although these ethical issues are normally detached from the research process, the moral integrity of a researcher is critically important to ensuring a trust worthy and valid research findings (Hesse \&Biber, 2007)

To mitigate the above, the following were done; I got a letter from Jaramogi Oginga Odinga University of Science and Technology introducing me as a Phd student in the process of data collection. The letter made it easier when I approached the respondents. An introductory letter explaining details of the aims of the research was also written. On informed concent, each participant signed a consent form as suggested by Cohen et al 2007) for freely accepting or declining to participate in the interview. The letter also indicated that participants would be free to include their names or not or to use other names to ensure confidentiality and real names used as suggested by Maree, 2012. Further to ensure confidentiality, real names of participants were replaced with codes (See Appendix I appendix L) as suggested by Wengraff (2001) and Bell (2007) whereby principals were coded as P and ranged from P1 to P21 while Sub county Staffing Officers were coded as SCS and ranged from SCS 1 to SCS 6 with TSC county director being coded as CDTSC.I also assured participants of making available the completed thesis if they wished to read. Participants were made aware that they had the right to withdraw from the study at any time and that their participation was voluntary as suggested by Burns (2000).

Staffing policy and recruitment of teachers being a sensitive issue, the information shared was carefully selected so as not to cause harm to the participants (Bryman,2004) and upon completion of the research, I promised to destroy the data and the tape information. Data obtained from the respondents were treated as confidential (Robinson, 2002). On honesty and accuracy, data collected were transcribed together with verbatim quotes in the analysis maintaining the original words of the interviewees. Issues of validity and reliability were considered throughout the research process of data collection, analysis and interpretation (Creswell 2014; Bell, 2003). The researcher paid careful attention to details during data collection and analysis to ensure trustworthiness of the research process. On reliability, interviews were audio-taped by the researcher. Other interviewees were consulted for confirmation as part of checking the accuracy of the interviewee (Burns, 2000). 


\section{RESULTS, INTERPRETATION AND DISCUSSIONS}

The results and focused discussions of data collected are presented in this chapter based on objectives of the study. Findings are presented and discussed under the following themes derived from the objectives;

1. Staffing policies in Kenya's public secondary schools.

2. Extent of Implementation of staffing policies.

3. Various challenges influencing the implementation of staffing policies in Homa-Bay County.

4. Coping strategies being employed to address these challenges.

In discussing the results, references were made to the literature reviewed in chapter two and any other literature used in the course of the research that was not cited in the literature review. The discussion was based on data collected through questionnaire and in-depth interview during the study but first the results on the demographic data of the sample of the study.

The return rate of questionnaires stood at $91.8 \%$ from the teachers respondents and $98.1 \%$ from head teachers. Since questionnaires were distributed personally by the researcher.95.9\% of the questionnaire were properly filled. Return rate from the interviews was $100 \%$. Interviews involved 21 head teachers, six sub County staffing officers and one TSC County director.

\subsection{Staffing Policies in Kenya's Public Schools}

The research question responded to was; what are the staffing policies in Kenya public Secondary schools? The respondents were asked to explain various staffing policies that have been implemented in their schools noting that different schools were at different levels and age. Responses were received through interviews and from the questionnaire. The results were as in Table 4.

\subsection{Staffing Policies in Kenya Public Secondary Schools}

\begin{tabular}{|l|l|l|}
\hline Year & Staffing Policy & No of Schools \\
\hline $1963-1998$ & Supply driven & 28 \\
\hline $1998-2001$ & Freeze & 112 \\
$2001-2015$ & Demand/Decentralized recruitment policy & 283 \\
\hline
\end{tabular}

From Table 4.3 responses, Homa-Bay County have school that have been affected by different staffing policies. The supply driven staffing policy benefitted a very small proportion of schools (28) 9.8\%.These are the only schools that were staffed using this policy as they were the only ones in existence. This had an impact from 1998 when the freeze on employment was done. The few number of teachers in the 28 schools were redistributed when new schools were up coming. This went on up to 2001 when the freeze was lifted. The teachers from these schools were deployed as deputies and head teachers in the upcoming schools and since there were no replacements, the old schools became understaffed. As at 2001, the number of schools had risen to 112 and all were affected by the freeze.

The onset of decentralized teachers recruitment in 2001 brought a little relief but was quickly eroded in 2003 when many schools were established through CDF. Between 2001 and 2015 more than 143 schools have been established. The decentralized teacher recruitment though a relief, it did not address transfers and turnover that existed during the freeze period moreover the number of vacancies were much lower than the number of schools. Not all schools were catered for.

During the interview, respondents revealed that there were schools that existed in the colonial period and were staffed according to the prevailing norms. The missionaries introduced western Education alongside Christianity (Sifuna, 1992). Education during colonial period was structured along racial lines. There existed "European education "an "Asian education" and "African education" divided by rigid boundaries (Ominde, 1964) No school in Homa-Bay County was established along racial line. Mission schools existed alongside colonial schools each staffing its own schools .This affected Homa -Bay County and the impact is still being felt in terms of facilities and staffing. School established by the government were better staffed with trained teachers compared to mission schools and trained teachers in mission schools moved to government schools at independence. During interview with an elderly head teacher ( $58 \mathrm{yrs}$ ) who was a student at the time of independence, he revealed that: 
Many schools under missionaries were deserted by teachers. Teachers rushed to government schools despite good facilities in the mission schools and that some of these schools have not recovered their glory due to staff exodus (P 18).

Independence brought sweeping reforms in staffing policies. Posting of teachers was harmonized under TSC established in 1968 to employ ,transfer, promote and deploy teachers From independence, staffing became "Supply" driven due to the acute shortage created by exiting Europeans (Nzuva, 2005). Expatriates had to be replaced as soon as possible. This supply driven policy had little impact in Homa-Bay County since at this time very few schools existed and it only favoured established schools that had ability to attract and retain graduates. A head teacher interviewed reported:

that supply teacher recruitment did not benefit Homa-Bay County much as it had very few schools approximately 74 with one sub County having only 7 schools by 1995 (P4).

The supply driven staffing policy continued up to 1998 when the government with the advice of World Bank and International Monetary Fund (IMF) froze teacher employment (Nzuva, 2005). This freeze greatly interfered with upcoming schools in Homa-Bay County. Young schools could not employ on BOM terms and the situation became worse when these few teachers were promoted and transferred to schools started by Constituency Development Fund (CDF) from 2003.

In 2001 the freeze on teacher recruitment was lifted and decentralized teacher recruitment introduced. The project was expected to meet the private demand of education and interregional distribution of teachers (Psacharopoulos \& Woodhall, 1994). According to the government officials decentralization was to promote efficiency and teacher retention (ROK 2000). It was meant to refine strategies and choose between possible options for system restructuring (Gaynor, 1998). Besides improving efficiency, decentralization empowered parents and communities in that they were able to participate in the recruitment and supervision of teachers (TSC, 2002).

Decentralized teacher recruitment came with the bonding policy whereby teachers were to stay in a station for at least 5years (Daily Nation, July, 31st 2003). This policy has favored upcoming schools particularly those in remote areas that could not attract teachers on transfer. A head teacher interviewed said:

Decentralized teacher recruitment has saved many school. Many schools would have collapsed due to teacher shortage but interviewees have no option but to go where vacancies exist and stay for 5 years. (P3)

Regular vacancies are advertised by TSC based on school's curriculum Based Establishment (CBE) however certain factors have continued to influence the implementation of these policies as will be seen in this study. This confirms the sentiments of Otieno (2007) that teacher recruitment and implementation of staffing policy has remained an issue in most rural public schools.

\subsection{How Teachers' Staffing Policy are Implemented in Homa-B ay County}

To examine the extent to which teachers' staffing policies were being implemented in Homa-Bay County, teachers and head teachers were requested to rate the staffing process in terms of advertisement of vacancies, quick response to teacher recruitment and posting ,TSC support during teacher recruitment, declaration of correct vacancies and fairness of interview results. The research question responded to was; To what extent are the teachers staffing policies implemented in HomaBay County? Respondents were given various items to rate on how staffing policies are being implemented in Homa-Bay County. The items included corruption in advertisement of vacancies, quick response to teacher recruitment and posting, TSC support during teacher recruitment, declaration of correct vacancies and fairness of interview results. The responses were as indicated in the Table

\subsection{Extent of Implementation of Teachers Staffing Policies in Homa-Bay County}

\begin{tabular}{|l|l|l|l|}
\hline Issue & Rating & Fairly efficient & Less efficient \\
\hline & Efficient & Fach & 11 \\
\hline Incorruptible advertisement of vacancies. & $71 \%$ & $17 \%$ & $69 \%$ \\
\hline Quick response to teacher recruitment and posting & $22 \%$ & $9 \%$ & $49 \%$ \\
\hline TSC support during recruitment. & $38 \%$ & 13 & $34 \%$ \\
\hline Declaration of correct vacancies. & $44 \%$ & $22 \%$ & $52 \%$ \\
\hline Fairness of interview results & $28 \%$ & $20 \%$ & \\
\hline
\end{tabular}


From Table 4.4, majority of respondents supported the fact that TSC is efficient in advertisement of vacancies without corruption. $71 \%$ agreed that there is no corruption together with $17 \%$ that rated it fairly efficient. Only $11 \%$ felt that it was less efficient. This means that when TSC is advertising vacancies there is very little or no corruption. According to respondents, it is done fairly and transparently although a few $11 \%$ cited issues of lobbying and networking but this did not constitute open corruption. This finding therefore contradict that of Otieno (2007) who noted that decentralized teacher recruitment has had issues citing corruption as one of these issues also as noted by Bosire (2003).

A good number of head teachers and teachers agreed that the vacancies were based on returns submitted with some travelling to press their cases. Quick response to teacher recruitment and posting was poorly rated at $22 \%$ and $9 \%$ felt that it was efficient respectively but majority $69 \%$ indicated that it was less efficient. This means that the process is very slow. A lot of time is lost from the time the vacancy falls to the time of recruitment and even after recruitment, official posting takes very long even up to 5 months.

TSC support during recruitment was positively rated.51\% out of respondent felt it was fairly efficient or efficient compared to $49 \%$ who considered it inefficient. Those who rated it efficient were majorly teachers who were interviewed. Head teachers however noted the few number of TSC personnel in the field making them stagger the interview dates to fit their programmes. The small number of TSC personnel also impacted on teacher evaluation since the process is hurried within a short time.

Declaration of correct vacancy was positively rated.66\% reported efficient and fairly efficient with only $34 \%$ reporting less efficient. Those who reported less efficient noted the struggle head teachers had to change the vacancies in their schools and the fact that in certain circumstances one combination could be advertised for two consecutive periods however the item was rated positively because most schools lack teachers in virtually all subjects and whichever advertised will be suitable for them.

Fairness of interview results was poorly rated. Only $28 \%$ felt it was efficient and $20 \%$ fell it was fairly efficient while $52 \%$ viewed the interview results are less efficient. This means that majority do not have confidence in the outcome of interview results. The outcome was seen to be affected by composition of interview panel, who were more or less not very well educated. In case of a tie between candidates, subjectivity was involved.

From the interview, it was clear that policy as stated is different from policy in use not only in HomaBay but Nationally .A central consideration in analysis of policy package is the degree to which the process addresses most salient dimensions of the problem across the system but this was not the case in Homa Bay County .From the interview it was noted that as much as decentralization was done on recruitment, a lot of control is still with TSC headquarters. Various items of evaluation rated low.

Quick response to teacher recruitment and posting was considered very poor at-22\%.The time taken from the time a teacher exit or vacancy identified up to replacement can take up to 3 years and in many cases spell doom to a cohort of students and even after the interview posting also delay a lot. This confirm the concern of Gitonga (2014) who noted that some teachers interviewed in August 2013 and were to report to work in Sept $1^{\text {st }}$ had not received their letters.

One Sub-County office observed that:

advertisements are routine requirement. It does not mean everything is ready and therefore you cannot tell when employment will be formalized and posting done. (SCS5)

Similarly another staffing officer when responding to inquiries from some candidates who were impatiently waiting for their letter and called during our interview observed that:

employing for 47 counties is not easy. Each case must be scrutinized on one to one basis at the headquater with the County staffing officer and therefore it must delay. Our bosses at the headquarter cannot just give blanket okay to what we approve in the field. They must vet them keenly and this require time depending on the number of recruits and sometimes the appeals or complaints raised." (SCS2)

On delay the researcher sought the opinion of the head teacher who although had not recruited but sat in some panel. He noted that they raised the issue with the headquater. He blames the delay on bureaucracies in government: 
TSC is just doing their work to advertise and recruit which they are doing well and efficiently but, they have to consult the ministry of education who must in turn consult Treasury. All this causes delays TSC on releases money when they are sure of the money. (P9)

This findings confirm that of Gitonga (2004) who noted that teachers interviewed in August and who were to report for duty in September 2013 had not received their letters at as February 2014 making the situation more difficult. The findings is further similar to the concern of Muindi (2013) whereby KNUT and KUPPET Kisumu branch chairmen asked TSC to release letters of teachers interviewed in August. These appeals were made in December after a long wait.

Another issue was corruption in recruitment and teacher management process being rated at $7.7 \%$. Staffing process have not become incorruptible right from advertisement to transfers and deployment .Bonding policy was meant to ensure staff stability but this has been watered down by corruption .Reports about head teachers corrupting their ways to get chance to recruit is common in the media and even when these teachers have been employed, they easily corrupt their transfers against the bonding policy as highlighted by The Standard Newspaper of January $1^{\text {st }} 2014$ "TSC in danger of devolving corruption to counties" highlighted how teachers have not realized the fruit of devolution despite lobbying for TSC to be a constitutional body. In the report, a Union official claim that transfers are easily worked in hours depending on who you know and what you have "as an officer of the union on the ground ,I can comfortably say without fear of contradiction that a day hardly passes without complaints from teachers of some rogue TSC officers at the County trying to solicit fund from them in order to get transfer to certain station .Matters are made worse when the same officer claim to be untouchable due to their blood relations with the senior most leadership at TSC." Head teacher confirm this disregard to five years bonding period and reported that;

TSC is the employer we are just agents and what they say is final. Occasionally your teacher brings you his or her transfer letter yet she or he has not completed the five years bonding period and you did not even sign the form. When you try to complain, it is treated as insubordination though occasionally we are promised replacement (p13.)

Corruption in recruitment is not only limited to Kenya or teaching. It has been reported in other parts of the world with some officers being prosecuted. In June 2008, OP Chantala and 53 others were charged in connection with appointment of 3216 Basic teachers in the state of Haryana during 19992000. He was found guilty of illegally recruiting over 3000 unqualified teachers. On $15^{\text {th }} \mathrm{July}$ New Delhi court reserved its' verdict in regards to the appeal of Chantala. A similar scenario was witness when the Director of Vigilance (DVAC)exposed alleged corrupt practices in the recruitment of teachers in a government aided school at Arani in Vellore district. Following a tip off that candidates paid huge bribes to get appointed as B.T Assistants in the Subramania Sastriar high secondary school, a special team conducted a surprise check and seized RS-23; Lakh from the head teacher's room. Preliminary inquiry with the newly appointed teachers revealed that they paid bribes on demand to the school authorities (Tuko.co.ke, 2015) This points to the level of corruption on recruitment.

The problem of corruption in teacher management and policy implementation was also echoed by KUPPET secretary. He noted that "without proper checks and balances, in the devolved TSC County offices, the Commission may end up climbing the ladder and topping the list of the most corrupt institution in Kenya"(2014, January $1^{\text {st }}$ The Standard). With corruption ripe in TSC implementation of staffing policies have been hampered. In Homa-Bay County cases of request to join spouse and domestic violence has been used to disregard the bonding policy. A Sub-County staffing officer while commenting on the issue of corruption said:

in these offices there are many people and it is hard to tell who is corrupt since you do not know the office visited moreover we cannot act without formal complaint.

Those who want short cut will always corrupt. (SCS4).

This scenario explains why female teachers easily transfer and their places remain unfilled. It also explain why some school and head teachers are reluctant to receive female teachers. Another SubCounty staffing officer said:

Sometimes it is not an issue of corruption but reason given for transfer. Issue of security and need to join spouse are easily considered as per TSC policy. In such a case bonding policy is secondary. (SCS1) 
Another head teacher who was asked why teachers easily leave his school and always understaffed despite the good location of the school reported that "my school is well located yes but has been misused;

Many officers in this district headquarter want their spouse posted in this school but when they leave, they leave with them and the gap remains. Better those schools in the interior staffed with female teachers operating from their homes. They can settle for long.(P19)

The above concern concurs with the findings of Bosire (2003) who observed that recruitment of teachers has been dogged by complaint of irregularity whereby BOM and school heads have been accused of favouritism. Implementation of staffing policy also rated low in terms of declaration of correct vacancies at $44 \%$.TSC is expected to act on returns submitted by the head of institutions however cases of head teachers requesting TSC to change the advertised subject have been common in Homa-Bay with 6 in 2014 and 8 in 2015. It is also common to find a particular subject advertised for the same schools in two consecutive years which therefore does not serve the purpose. A head teacher interviewed expressed his frustration of having to travel to Nairobi 3 times to request to change subject combination as this was the second time he was given same combination.

I have been to the TSC headquarters to change the combination twice but in vain. The TSC County director is now handling the matter. The subjects I have been given are the same one I got last year. (P2)

The same problem was raised to the sub County staffing officer who reported that:

We can blame both the head teacher and TSC. Some head teachers do not give exact figure on staffing situation, and TSC still rely on earlier request. TSC can be blame for failing to update their records and rely on outdated statistics. The yellow forms containing staffing position per school rarely reach on time and they act on earlier request. (SCS5)

Another Sub County staffing officer had this to say concerning advertisement of similar combination and exonerated TSC from the blame:

TSC knows the staffing needs of each school and has discretion to act according to CBE of each schools. Efforts to change are creation of some head teachers who want convenience themselves or those who want chances for their relatives or teachers they already have on BOM. (SCS6)

With these responses, it shows that sometimes the right vacancies are never declared except who to blame is unclear. Policies are meant to address salient dimensions of staffing problem and the fact that these anomaly exist achieving equitable distribution of teachers is hampered. On the same vein fairness in distribution of vacancies has not been enhanced as some schools recruit every year while some even take 3 years to get a teacher. A sub-County staffing officer confirmed this and attributed the problem to few vacancies. He observed that:

There are over 6000 secondary schools countrywide and when only 2000 chances are given, majority of schools must miss but remember they cannot be sure of next year or next recruitment since some schools shall have emerged with more serious needs. (SCS 1)

Ahead teacher interviewed also confirmed that some school have not been getting slots since inception. These schools only rely on transferred teachers who are sometimes problems in their previous station and rarely stick however the head teacher blame their colleagues for missing on recruitment:

Some of us are in their comfort zone and never bother to knock these offices. Networking is important but some of our colleagues don't value it. They are comfortable since parents are charged to pay BOM teachers in their schools. Let them make extra efforts to remind TSC. (P16)

Declaration of correct interview results was another lowly rated at $28 \%$. The process of interviewing and selecting the right teacher are occasionally not transparent. Many people have doubt with the results given after interviews. $60 \%$ believes that there are manipulation particularly where there is a tie and section $\mathrm{C}$ which are subjectively given. Sub County staffing officer who has been attending the recruitment process had this to say:

During interviews we have guidelines. Section $A$ and $B$ are very objective but part $C$ is determined by members of the panel. The panelist easily use it to favour or disadvantage candidates for different reasons. (SCS 6). 
Similarly a head teacher shared the same thinking and supported his action:

You have had a teacher on BOM helping the school and earning very little. When a vacancy comes, it will be unfair to leave this person especially when there is close competition. You arrange with the panelist to consider him. (P20)

This finding concurs with that of Opiyo (2003) who reported the concern of KNUT secretary "the process should be free and transparent to ensure that the most qualified applicant get the job". $\mathrm{He}$ added that "We do not want to hear of corruption, nepotism, political interferences and favors during the interviews". These fears of KNUT and KUPPET occasionally exist and therefore the extent of policy implementation is put to disrepute. The findings further concur with that of Bosire (2005) which noted that recruitment exercise since 2003 has been dogged by complaint of irregularity. Schools and district boards tasked with the exercise have been accused of nepotism and bribery, In certain cases people recruit close relatives which greatly affect the results. Other than favour for those employed on BOM, occasionally community interest prevail and panelist from the community favour their own. A head teacher interviewed told the researcher that:

Communities view schools as their property and an investment where they must benefit.They tend to favour their "person" at all cost. (P14).

This was confirmed by the staffing officer who said that results have been nullified by TSC when it is proved that provisions were breached to favour a particular candidates. This favouratism partially explains the presence of many teachers from within Homa-Bay County.

TSC support during recruitment was equally rated low at $28 \%$. As the employer, TSC officers are supposed to oversee the process individually in all the schools and districts, however the few officers in the field cannot oversee or supervise the entire process within the time provided.A report by one sub-County officer interviewed:

Revealed that overseeing 28 recruitment within 4 days was not practical and therefore subjected the whole process to manipulation. He said that this explains why some results ends up being nullified (SCS 4).

Ahead teacher who has participated in the exercise confirmed this. He noted that:

The exercise is always rushed whereby a whole sub County is expected to conduct centralized recruitment in one day with few minutes given to each school. with this arrangement, proper scrutiny and vetting is not possible. The situation is made worse when more than one panel is created and the staffing officer sit on them in turns. In his absence from a particular panel, the outcome may be questionable.(P8)

Another weakness noted was teacher evaluation during the interview .A sub County director revealed that:

There exit weak teacher evaluation. The process lack vigour and depth. Consideration are given to academic qualifications only. (SCS1)

This findings concurs with that of Ingersoll and Smith (2003) who observed that most recruitments are done through application and internet without vetting. The lack of capacity to vet teachers is further complicated by the composition of the vetting Boards as confirmed by Otieno (2003) "I wish to bring to the attention of the ministry of education that interviews to recruit secondary school teachers are not based on merit... as most Board members have low level of education". A head teacher interviewed had reservation on the boards who conduct interviews particularly in the upcoming school.

Nobody in my committee can interview a candidate from outside our tribe. They can neither express themselves in English nor Kiswahili leave alone the subject content. Interviews ends up being a two man affair i.e. the head teacher and TSC representative. (P6).

Implementation has not been keen on relevance of the teachers to the school or subject need. The presence of teachers with PGDE in Homa-Bay County confirm that some of those who joined teaching have alternative training and aspirations and probably not very relevant for example people with Bachelor of Education technology have no teaching methodology to teach physics and mathematics. A Sub County staffing officer observed: 
that vacancies are kept as secret until released on News papers or internet together with the deadlines. The duration is short to allow an excellent search. (SCS1).

Staffing policies was found not to have addressed increasing and fluctuating enrollment in schools occasioned by subsidized secondary Education.TSC normally have long term and medium term plans that cannot address immediate challenges. Staffing and CBE are based on previous statistics and National economic situation. School enrollments have been fluctuating depending on KCSE and KCPE result but TSC policy is not flexible enough to deal with the situation immediately. With the above short comings, TSC officers in Homa-Bay County have tried to follow policies however a little success has been realized. Ahead teacher decried the fact:

that some schools have more teachers just because they at one time had 3 streams but now has gone to single stream yet some who have moved to 3 streams cannot get adequate teachers due to their past registration. (P13)

\section{SuMmary, CONCLUSIONS AND RECOMMENDATION}

In Kenya staffing policies have changed from time to time. Homa-Bay County has gone through the different staffing policies right from inception of Education where staffing was by different bodies. The supply driven staffing policy existed in Kenya after independence and there are schools in Homa -Bay County that benefitted together with demand driven .The current staffing policy is decentralized demand driven and many schools have benefitted owing to the young nature of schools .Many young schools have attracted teachers through this policy.

Homa-bay County like other parts of the country has been guided by the policies. TSC and ministry of education officials have stuck to these guidelines when recruiting and posting teachers however certain limitations and constraints has made policy as stated and intended to be different from policy in use these includes corruptible advertisement of vacancies, slow response to recruitment and posting ,weak support during recruitment, declaration of correct vacancies and declaration of correct interview results. Staffing policies have not responded to fluctuating student enrollment instead stick to long term plans.

\section{Conclusions}

The study concluded that various staffing policies since independence have been applied in Homa bay County with varied degrees depending on the number of schools that were in existence. There are schools that were affected by racial and religious provision and staffing though few. There are schools that benefitted from the supply driven, the freeze on employment and those that have benefitted from demand or decentralized teacher recruitment program.

The study investigated in the second objective how staffing policies are being implemented in HomaBay County and concluded that like other parts of the country, staffing policies have formed guidelines for Homa-Bay County. The education staff have tried to implement policies as stated however the study noted deviation in terms of quick response to teacher recruitment. The study reported that the process took too long for vacancies to be advertised and filled. Also noted was that TSC support during recruitment was not strong owing to the few personnel to supervise the exercise and the short duration within which the exercise is to be conducted. The study concluded that there was fairness in the declaration of correct vacancies even though some schools received similar combination twice consecutively. The research concluded that there were doubts about interview results. It concluded that it was prone to manipulation due to the composition of the boards of management and favoritisms from the local communities.

In light of the findings, the following recommendations were made;

1. To achieve equitable distribution of teachers for all schools staffing policies should be varied to respond to the needs of old and young schools alike. Schools that existed prior to independence should not be treated the same way like those started with the advent of CDF and where possible special slots be given to certain areas and schools.

2. The government through TSC and education staff should enforce the staffing laws firmly particularly the bonding policy. This will ensure staff stability. Shortcuts and deals which enable teachers to transfer before bonding period should be minimized. Local education staff and TSC agents should be empowered to reject such manipulations. 
3. To attract and retain teachers, areas classified as hard ship zone with hardship allowances should be expanded. Certain areas were left initially but are equally needy. This will make teachers to feel well compensated for the hard conditions.

\section{Suggestion for Further Research}

In line with the findings, research should be conducted in the following areas.

1. Methods of streamlining and strengthening Decentralized teacher recruitment policy.

2. Impact of the Administrative, Students, School and Individual teacher related factors on academic performance in Homa-Bay County.

\section{REFERENCES}

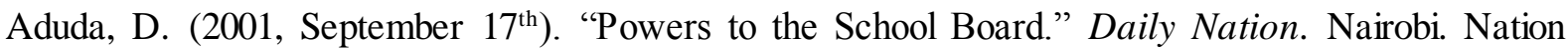
Media Group.

Alensworth E. Poniscick \& Mazzeo, C. (2009) the schools teachers leave. Teach mobility in Chicago Public schools, Chicago ii consortium on, Chicago school Research Retrieved October 1,2009 from http/ccr. Uchizagu.educ/publication/ccr, Teacher mobility paf

Allen, M.B.(2005). Eight Questions on teacher recruitment and retention; what does research say? 700 broadway, Suite 1200, Denver; Education Commission of the states. Retrieved $23^{\text {rd }}$,January 2012.

Allensworth, E., Ponisciak, S. \& Mazzeo, C. (2009). The school teacher leaver: Teacher mobility in Chicago primary schools. Consortium on Chicago school research. University of Chicago.

Alliance for Excellence Education (2008). What keeps good teachers in the classroom? Understanding and reducing teacher turnover. Washington DC.

American Association (1999). Senate Employment, Education Training Reference Committee (1998).

Ariko, C. (2006). Factors Influencing teacher transfer request in Suba District. Unpublished master thesis. Maseno University.

Ariko, C.O. (2009). Factors influencing Secondary School Teacher Transfer request in Suba District Kenya. Unpublished measles of economic thesis Maseno University.

Ary, D., Jocob, L., \& Reviarich, A. (1996). Introduction to research in education (5 ${ }^{\text {th }}$ Education) Fort worth. Harcourt. Bruce publishers.

Babbbie, E. (2007) . The practice of social research(12 $2^{\text {th }}$ Ed) U.S.A Chapman University

Backley, J., Schneider, M. \& Shang, Y. (2005). Fix it and they might stay: School facility quality and teacher retention in Washington DC. Teacher called record 107(5) 1107-1123.

Bacolod, M. P. (2007). Do alternative opportunities matter: The role of female labour markets in the decline of teacher quality. Review of Economics and Statistics 89(4)737-75.

Ballou, D. \& Podgusky, M. (1993). Teacher attitude towards merit pay; examining the conventional wisdom industrial and labour relations Review 47:50-60.

Bassey, M. (2002). Case Study Research in Coleman, M. \& Brigs A.R.J. Research method in Educational Leadership and Management, Paul Chapman.

Beck,C. \$ Kosnik, C. (2001). From cohort to community in a pre-service teacher education17(8)925948

Beeri, T.A.(2005). Co-curriculum Activities. New Delhi thrissur publications.

Bell, J. (2007). Doing Research project a guide for first time researchers in education, health and social success. England: Maiden-open University

Benel, P.S. \& E. Kadzamira, (2003). The Impact of the Aids epidemic on teachers. University lectures in Malawi (fort hong).

Betts, J.R., Reuben, K.S. \& Dan emberg, A. (2000). Equal resources, equal outcomes? The distribution of school resources and student coherent in California. San Francisco; Public policy Institute of California.

Bobbit, S., Leich, M., Whitener, S. \& Lynth, H. (1994). Characteristics of stages, money and learners; Result from the teacher following survey 1991-1992. Washington DC, Nairobi centre for Education statistics. 
Boe, C.E. (Robbits, S. A., Cook, Lit, Whitener, S.D.S., Weber, A.L. (1997). Why didst this go? Predictors of Retention, transfers and attrition of school and general education teachers from a national perspective. The Journal of special Education, 30, 390-4.

Bogonko, S.N. (1992). A history of Modern Education in Kenya (1895-1991). Nairobi; Evans Brothers (K) Ltd.

Booker, K.\& Glazeman, S. (2009). The Effects of the Missouri career ladder. Programme on teacher mobility and Retention (MPR Reference No. 6333-400). Washington DC. mathematical Policy Research.

Boyd D., Grossman, P., Lankfort, H., Loeb, S., \& Wyckoff, J. (2006). How changes in entry early requirements after the teacher workforce affect student achievement. Journal of Education Finance and Policy 1(2) 76-216.

Boyd D., Grossman, P., Lankfort, H., Loeb, S., \& Wyckoff, J. (2007). Who leaves? Teacher attrition and student achievement. Research paper. Albany New York Teacher policy research.

Boyd, D., Grossman, P., Lankfort, H., Loeb, S., \& Wyckoff, J. (2005a).Explaining the short covers of high achieving teachers in schools with low performing students. America, Economic Review policy 95(2)166-177.

Boyd, D., Lankfort, H., Loeb, S., \& Wyckoff, J. (2005b). The draw of home: How teachers preference for proximity disadvantage urban schools. Journal of labour economic 14(2) 313-339.

Boyd, J.D., Grossman, P.L, Hamilton, I., Lankford, S., Loeb, J. \& Wickoff, H. (2009). The influence of school administrators on teacher retention decisions. Stanford University

Boyd, Lanfurd, Loeb, H. \$ Wyckoff' S. (2005) Explaining the short careers of high Achieng Teachers in schools with low performing students. America Economic Reviews,95(2):166-171.

Brill, S. (2009). The rubber room, the battle over New York City worst teachers. New York.

Brindley,G. \& Hood,S. (1990). Curriculum innovation in Adult ESL.Inc. Brindley(ed)the second language curriculum in action(Syney: National Centre for English language teaching and Research. p 232-248.

Brox, J. (2012). Leadership and employee turnover. Available at file: //1//c:/documents and settings/admin/desktop/whoisresponsibleforemp/accessed September $9^{\text {th }} 2012$.

Bryman, A. (2008) Social Research Method( $3^{\text {rd }}$ education) New York: Oxford University press.

Bulach,R., Booth, D.\& Michau, P. (1999). Analyzing Behaviour of school principals, paper presented at Association for the advancement of Educational Research Conference. Florida; Pointevedra.

Bulter, D. \& Duncombe, W. (2008). Recruiting highly qualified teacher. Do district recruitment practices matter? Public Finance Review 36(1): 33-62.

Chepkemboi, J,Nyangechi,A. (2010) Factors influencing Teachers Employees turnover in west Pokot District.

Creemer, B.P.M. \& Kyriakider, L. (2006). Critical analysis of the current approaches to modeling educational effectiveness. The importance of establishing a dynamic model school effectiveness and school improvement.

Chimbganda A.B .(1999). Teacher burn out in Botswana ESL Secondary school classroom Journal of language Teacher 33,141-158

Clotfelter, C.T., Glennie, E., Ladd, H.E., \& Vigdar, J. L. (2006). Would higher salaries keep teachers in high poverty schools? Evidence from policy intervention in North Carolina Cambridge, MA: National Bureau of Economic Research.

Cohen,l, Manion,L \& Morrison, K. (2007). Research Method in Education, London, Routledge Falmer.

Craig, H.J Krapf \& Plessis, J.(1998). Teacher Development :making an impact Washington DL,Agency for international development centre. Texas A \$ M

Creswell, W. J. (2014). Research Design, Qualitative, Quantitative and mixed method approaches. $4^{\text {th }}$ Edition Sage Publication. New York.

Creswell, J.W. (2003). Research design: Qualitative, Quantitative and Mixed Method approaches. Thousand Oaks, C.A. sage 
Croasmun, J., Hampton, D \& Hermann, S. (1997). Teacher attrition; Is time running out? Electronic research working paper, School of Education, University of North Carolina at Chapel hill, available from http://horizon.un.educ/project/issues/papaers/Hampton.asp. retrieved April 2008.

Dana, B, Duncombe (2004). Recruiting highly qualified teachers. Do Districts recruitment practice matter? New York. Maxwel School of Syracuse University 426 Egger hall.

Danham, J. (1992). Stress in teaching. $2^{\text {nd }}$ Edition. Rutledge Publisher. London and New York.

Darlin, R. \& Scheider, L. (1994). Understanding Job Satisfaction in primary and Principals, Urban and Suburban. Urban Education 29 (1) 63-88.

Darling Harmond, L. (2009). The Right to learn: A blue print for creating school that work. Josseybass .

De walque, Dmier, Jessica S Nakiyingi, june Busingye and Jimmy.A. whitworth(2005) changing association 11 years in Rural population cohort in south West Uganda. Tropical medicine and international health 10(10)993-1001

Delano, L.R. Crookes, G. (1994). The meaning of Innovation in for ESL teacher system.vol 22 no (4): 487-496.

Denzin, N.K. \& Lincoln,Y.S. (2000). Collecting and interpreting Quantitative materials. London sage

Education Act. (2002). www.opsi.gov/actof 2002.

EFA Global Monitoring report. (2005). Education For All. The Quality imperatives. Paris UNESCO. EFA 2009.

Eisinga , R., Te Grotenhais,M \& Pelzer, B. (2012). The Rehability of two-iten scale Pearson Cronbach or spearman-Brown? International Journal of public Health VOL 58(4) 637-642.

Emmie, K. \& Sang, A. (2008). Teacher Recruitment in Secondary School. Policy and practice in Kenya. Unpublished M.Ed Thesis. Moi University.

Endawoke, Y.(1997). Self-Efficiency, perceived importance. Attitudes and Achievement in Physics among Tana Haik Compresusie secondary school(male and female students) Apath analysis, Ethiopia journal of Education,1c(1).

Evers, \& Lokomski (2003). Theories of Education leadership and management. Third Edition. Sage publication Ltd. London.

Farkas, S., Johnson, J. \& Folens, T. (2000). A sense of calling: Who teaches and why. New York; Public Agenda.

Feng, L. (2005). Hire today, Gone tomorrow, the determinant of attrition among public school teachers. Tallahassee; department of communication 288. Bellany, florida state university.

Fisher, D.C., Schoenfelt, F.L. \& Shaw. B.J. (2009). Human Resource Management. USA. Pearson Education.

Fontane, A. \& Frey, J. (2003). The interview. From structured Questions to Negotiated Text: In N. Denzinad Y. Lincoln(Eds) collecting and interpreting Quantitative materials London: Sage

Frank, E. (2008). Firing tenured teachers isn't just difficult. It costs you. http://www./usatoday.com.

Furham, A. (1997). The Psychology of behaviour at work. Huve; Psychology Press.

Gabriela, G., Helman, D. \& John, H. (1998). The Utilization, Deployment and management of Teachers in Botswana, Malawi, South and Uganda. Synthesis report on sub regional workshop. p. 24-28. Paris.

Gary T. Henry et al Portal report: Teachers preparation and students test scheme on work Carolina 9(june

Gaynor, C. (1998). Decentralization of education, teacher management. Washington DC. World Bank.

General Teaching council (2001). www.opss.gov.uk/si/ss.

Gerald, L. (1992). American Issues. Publication Education. Round house publishing Limited. New York USA/ Oxford United Kingdom.

Glen, I. earthman, Education oversight committee for a south caroline publiv schools.

Gold, A. \& Evans, J. (1998).Reflecting on School Management. London, The Falmer Press. 
Goldhaber, D. (2008). Addressing teacher qualification gap. Exploring the use and efficacy of incentives to reward teachers for tough assignment. Washington DC. Centre for American progress.

Gregson (2006) HIV diseases associated with Behaviour change in Eastern Zimbabwe since 3 February 2006 vol 3 in no 5761,pp664-666

Griffin,G.(1996) School mastery; A straight Talk about Boarding School Management. $2^{\text {nd }}$ Edition. Nairobi, Lectern Publications ltd.

Guarino et al(2004) A review of the research literature on teacher recruitment and retention, prepared for the education commission of the states, RAND cooperation C.A P.T.O

Guarino, C.J., \& Dirkeland (2004). A Review of the Research Literature on Teacher Recruitment and Retention, paper for the educational crossing of the states RAM Cooperation C.A.

Handlesman, J. (2009). Understanding and Remedying Employee Turnover. Available at http://www.tool/com/news/newdetails2009.

Hanson, M.E. (1995). Decentralization and Decentralization in Columbia. Columbia Education comparative Education review. Washington DC. World Bank.

Hanushek, (2005). The Market for Research Quality; Working paper series, 11 154. National Bureau for Economic Research, Cambridge MA.

Hanushek, E.A,Kain,J.F \$ Rivkin,S.G(1999) Do higher salary buy better teachers? (working paper No 7082) MA: Ntural Bureau OF 400 Researchers, Retirement April 14200 for htt/www/org/ papers/w 7082

Hanushek, E.A., Kain, J.F. \& Rivkin, S.G. (2004). Why Public schools lose teachers; Journal of Human Resource 39(2) 326-354.

Harris, D. N. \& Adams, S.J. (2007). Understanding the levels and causes of teachers turnover. A comparison with other professions. Economic of Education Review 26(3) 325-337.

Hence, J. (2000). Progress through the teacher pipeline 1992-1997 college - Gazette and elementary /secondary teaching as of 1997. Washing D.C National centres for education statistics.

Henke, R.R. \& Chan, X. \& Gens, S. (2000). Progress through the teacher pipeline, 1992-1993, College graduates and elementary secondary school teaching as of 1997 NCEs 2000-152. Retrieved May $9^{\text {th }} 2006$ from http://rise.edgov/pubsearch/pubsintu.asp?pubid=2000152.

Hezberg, F. (1959). The Motivation to work. New York: John Wiley and Sons, Incorporation.

Hirch, E., Koppech, J. \& Knapp, M. (2201). Revisiting what states are doing to improve the quality of living; Update on Patterns trends.

Imazeki, J. (2008). Attracting and retaining teacher in high need schools; Do financial incentive make financial sense? San Diego.

Immonje, M. (1990). Comparative study of the factors that contribute to job satisfaction and dissatisfaction between teachers in private school and public primary school in nairobi. Kilimani Zone. Unpublished master thesis.

Indimuli, K. (2013, June - September). The Principal, Secondary heads professional magazine.

Ingersoll, R. \& Thomson, M. (2003). Educational Leadership 2003 Vol 60 No. 8 Keeping Teachers pg 30-33

Ingersoll, R. \& Perda, D. (2009). The mathematics and science teacher shortage: Facts and myths. CPRE. Research RR - 60 Philadelphia. Consortium for policy research in education.

Ingersoll, R.M. \& Kralik, J. (2004). The Impact of monitoring on Teacher Retention; what the research says. Denver, Co; Education Commission of the States.

Ingersoll, R.M. (1999). The problem of under qualified teacher in American secondary schools, Educational Research, 28 26-37. Available www.aera.net/rbs/er.28-02/ingersollhtm.

Ingersoll, R.M. (2001). Teacher turnover and water shortage, An organizational analysis . American Educational Research Journal 37(3) 499-534.

Ingersoll, R.M. (2002). The teacher shortage: A case of wrong diagnosis and wrong prescription. NASSP bulletin 86(631) 16-30. Available at www.princpals.orgnews/bltnteachershort0602htmc. 
Ingersoll, R.M. (2003). Who control teachers' work? Power and accountability in American schools; Cambridge MA: Harvard University Press.

Ingersoll, S.M. (2004). Why do High poverty school have Difficulty staffing their classroom with qualified teachers? Washington DC: Centre for American Progress.

Ingollo, D. (2000).An investigation of Job satisfaction and dissatisfaction among home science primary school teachers in Nairobi. Unpublished Masters of Education Project. Kenyatta University, Nairobi. Kenya.

Jacobs, B. \& Lefgven, L. (2006). When Principals rate teachers. Education next 6(2) 59-69.

Jason. A.Grissomn (20110 Can good Principals keep Teacher in Disadvantaged schools? Linking principals effectiveness to teacher satisfaction and Turnover in hard to staff environments, 113 TCHRS.C.REC2552,2552

Johnson, S. \& Birkeland, S. (2003). Pursuing a sense of success" New Teachers explain their career extension, American Educational Research Journal 4(3)581-6.7

Johnson, S. M. \& Berg, J.H. \& Donalson M.L. (2005). Who stays in teaching and why? A review of literature on teacher retention. National retired teachers association. Washington DC.

Juma, K.A. (2010). Factors Influencing Job Satisfaction among female secondary school Principals in Rachuonyo North and South. Unpublished Thesis, Maseno University.

Kadzamira, E.C. (2003). Where has All the Education Gone in Malawi: Employment outcomes of secondary and university learners. Brighton: Institute of Development studies.

Kamara, F. (2001). As a cute teacher shortage hits countrywide GTU President speaks out. The Daily observer/available at url:http:/a/africacom. stories/printable200210 accessed on 16th April 2012.

Kamima, W.K. (2002). A study of factors contributing to Job Satisfaction among special Education Teachers. Unpublished Masters of Education thesis. University of Nairobi. Kenya.

Karagu, G.K. (1990). An Investigation of Jon satisfaction /dissatisfaction among secondary principals and head principals in Nairobi; Kenya. Unpublished $\mathrm{PhD}$ thesis - University of Nairobi.

Karagu,G.K.(1998). Investigation of Job satisfaction and dissatisfaction among Elementary school teachers and head teachers in Nairobi .Unpublished Doctor of Philosophy Thesis, University of Northern Illinois.

Kasanda, P.(1993) School organization and problems encountered in Teaching Mathematics in Zambia secondary schools. Namibia Mazongororo Printers.

Kayizzi, K.B. (1991). "Predictions of Job satisfaction among graduate teachers in some selected Kampala secondary schools: Unpublished master thesis, Kampala Makerere University.

Kemei, T. \& Ouma,W. (2014). KNUT, Expect strike if no deal is struck. Sunday ,October $19^{\text {th }}, 2014$. Nation Media Group.

Khera, S. (2002). You can win. step by step Tools for top Achievers. New Delhi, Mcmillan.

Kihumba, K. (2009). Teachers Service Commission - Teacher Image Vol. 16. Nairobi Kenya

Kimengi, I.N. (1991). Factors determining commitment and non commitment to teaching among for primary school principals in three Districts: Keiyo Marakwet, Nyeri and Kakamega - Kenya. Unpublished $\mathrm{PhD}$ thesis, Kenyatta University.

Kiplagat, J.K. (2002). A study of the level of Job Satisfaction among public secondary school science teachers in Uasin Gishu district. Unpublished Masters of Education. University of Nairobi. Kenya.

Kipsoi, E. \& Anthony, S. (2008). Teacher Recruitment in secondary school; Policy and Practice in Kenya. Unpublished PhD Thesis. Moi University.

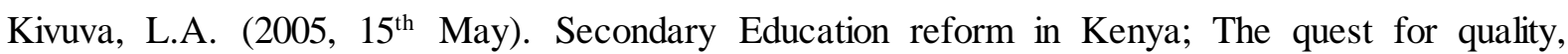
relevancy and equality. URL; http:/www.ginie.org/cstudents/africa/es-africa.htm.

Kizito, A. (2005). Factors, Trends and Effects of Teacher Attrition on student enrolment and Performance in Secondary schools in Kisumu city, Kenya. Unpublished master of Education thesis. Maseno University.

Kolbe, T. \& Catherine, O.S. (2005). Economic Incentive as a strategy for responding to teachers staffing problem: A typology of policies and practices Educational administration quarterly $V$ 48 N5 $p$ 779-813. Sage publication 
Effects of Staffing Policies on Public Secondary School Teachers' Distribution in Homa-Bay County, Kenya

Kombo D.K \$ Delno, L.A.T (2006) Proposal and thesis writing .An introduction . Nairobi, paulines publication Africa

Koontz, H. \& Weihrich, H. (1998). Management. New Edition. Mc Graw Hill Book Company.

Kyriakider, L. (2005). Extending the comprehensive model of educational effectiveness by an empirical investigation. School effectiveness and school improvement. 16

Lambert, T. (2003). Leadership capacity for lasting schools improvement; New York: Association for supervision and curriculum Development.

Lavin A(2006) Educating school teachers, Washington DC evaluation schools projects. Available at www.ed.school.org/teacher-report-htm

Lavy, V. (2002). Paying for performance, the effect of teacher's financial outcome on student's scholastic outcomes .Journal of political economy.Vol. 110,6 pp1286

Leinwand, P.L.D. (1992). American Issues. Public Education Facts File . New York Oxford. UK. USA Round House Publishing Ltd. Oxford United Kingdom.

Levine, H. M. (1985). Solving the shortage of mathematics and science teachers. Educational evaluation and policy analysis 7(4)371-82

Loeb, S. \& Myung, J. (2010). Economic Approaches to teacher recruitment and retention. Stanford University. Stanford, C.A, USA. Elsevier Ltd.

Loeb, S. \& Reinger, M. (2004). Public policy and teacher labour market. Eastlansing: Michigan state university. Education policy centre.

Loeb, S., Darling Hammond, L. \& Luczak, J. (2005). How Teaching corrections predict teacher turnover in California schools. Peabody. Journal of Education 80(3) 44-70.

Loslade, M., Inguarson L. (2003). Initiative to address teacher shortage. Australia centre for educational Research. Bourke Road Alexander.

Lucas, S.R (2013) "Beyond the existence proof: on logical conditions, epistemology, implications and in depth interviews research. Quality \$ Quantity, vol 19(7) 432-439 doi 10,0007/511/35

Lutta, S.(2014). Headteacher injured in highway attack four schools closed indefinitely. Daily Nation ,October $20^{\text {th }} 2014$ pg 3.Nation Media group.

Mac Donald, L. (2012). Remuneration and employee turnover. Available at file:11/C/documentsand setting/admin/desktop/information. Accessed September $9^{\text {th }} 2012$.

Maeke, E. (2009). School shake up; case study of Moi girls Marsabit.wwn.changemakers .com. Retrieved on 17/12/2009.

Maina, S.B.(2014, November $\left.27^{\text {th }}\right)$ Homa-Bay and Siaya hardest hit as health drive focuses on vulnerable group. Daily Nation, Nairobi, Nation Media Group.

Mannary,D. (2010). Making the familiar Strange: Can visual research method render the familiar setting more perceptinble? Quantitative research 10(10) PP 91-111. Returned from htt p:qrj sage pub.com/contention 10/1/14

Manson, M. (2010) Sample size and Saturation in PHD studies using Qualitative interview Forum Qualitative Social for schung/forum, Qualitative Social Research Vol 11(30, Art(30 Art . Retrieved from http:ii www.nbn-resolving.de/urn:de:0114-fgs 100387 on march $23^{\text {rd }}, 2014$.

Mapesela, B. \& Francois, S. (2015). Trend in the Management of Human Resources in Higher Education. Performance management of academic staff in South Africa High education: A developmental Research Project.

Maree,J.G. (2012). Career counseling in the $21^{\text {st }}$ century. Merging quantitative approach to facilitate best practices, Special Issue of the Cypriot. Journal of Education Science Vol. 7(1)1-4

Marvel, J., Lyter, D.M., Peltola, P., Strizek, G.A \& Morton, B.A. (2007). Teacher attrition and mobility; Results from the 2004-2005. Teacher follow up survey; US. Department of Education, National Centre for construction, Washington DC: US. Government Printing Office.

Mbugna and Reche (2012). Factors contributing to poor performance in Kenya, attitude of Primary Education in public, Day Primary School in Mwimbi Division Maara District Kenya International Journal of Humanities, Vol 2 No 5: March

Mc Neil, Pad chapman S. (2005) Research methods London: Routlledge. 
MC. Neil, P. \& Chapman, S. (2005). Research method. London Routeledge.

Middle wood, D. \& Lambayi, J. (1989). Educational Management, Research and Practice. Strategic management in school and colleges. Paul Chapman publishing limited London. UK.

Mikule, J. \& Arthur, W. (2008). Education Next. Vol. 8 No. 2. Recruiting and Retaining teachers in hard to staff schools. retrieved from www.afl.org./.../teacher/hardtostaff06.07-16th may 2007. at $3.00 \mathrm{pm}$.

Ministry of Education and Training. (2006). Annual Performance report. Mbabane. MOET.

Mobley, W. (1982). Employee Turnover; Causes, consequences and control. Reading, MA, AddsonWesley.

Moleni, C.M. \& Ndalama, L. (2004). Teacher Absence and Attrition Malaysia Primary Schools: A case study of Four District (Research report) Centre for educational Research and Training (Cert).

Morgan, D. (2006). Connected contribution as a motivation combining Quantitative and Qualitative methods. In L.curry, R.shield \$ T.WETLE(Eds), Applying Quantitative and mixed methods in Aging and public Health Research, Washington,DC.American public Health Association

Morgan. D. (2007) Paradinis lost and pragmatism Regained: Methodological implication of combining Quantitative and Qualitative method. Journal of mixed method Research, vol 1:48 PP 52-59 Dol :10.1177/2345678906 292462 Returned from htt p:morn sage prbliza.com/cg1/ context/abstract/1/1/48

Moskal, B. M. \& Leydens, J.A (2000) Scoring Rubric development: Validity and Rehability: Practical Assessment, Research \& Evaluation, 7(10). 149-163. http//www.pareanline,net/getvnasp? $\mathrm{V}=7 \$ \mathrm{n}=10$

Mukiebe,B.A. (2001). Special Education in Kenya. February 16 ${ }^{\text {th }}$ 2001.Daily Nation, Nairobi. Nation Media group.pg 8.

Mulkeen ( 2005). Teacher for Rural school: A challenge for Africa Afza regime world Bank working document. Addis Ababa world Bank sept 2005

Mulkeen, A. \& Chen, D. (2008).Teachers for moral schools. Experiences in Lesotho, Malawi, Mozambique, Tanzania and Uganda. Http/www-World Bank/externa14/27/2010 2pm.

Mulkeen, Aidan (2010). Teachers in Anglo phone Africa. The World Bank, Washington DC.

Mumane, \& Olsen (1990). The Effects of Schemes and Opportunity cost in legth of stay in Teaching; Evidence from North Carolina (The Board of Regents of the University of Wilcoms system).

Munga, A.M. Songstad, N.G., Blystad, A. \& Maestad, O.(2009). The decentralization-Centralisation dilemma, Recruitment and distribution of Health workrs in Remote districts of Tanzania. Biomed central ltd http/www.creative comm./org/licence/by/2. Retrieved 27/10/2011 at 2pm.

Murmane, R.J. \& Olsen, R. (1990). The Effect of salaries and opportunity cost on length of stay in teaching; Evidence from North California, Journal of Human Resources 25(1) 156-124.

Muthama, J.G.(2014). Alcohol and drug in school now alarming. Wednesday, October $15^{\text {th }}, 2014$. Nation Media Group.

Mutsotso, S.N.(2004). The role of social education and ethics in the management of students violence in Secondary school in Vihiga District. Unpublished Doctor of Philosophy Thesis, Moi University.

Nandala, F. I. (200). Teacher Recruitment and retention in private secondary schools in Kampala District. Unpublished masters of arts thesis, Kampala, Makerere University.

National Centres for Educational Statistics (2007). Teacher attrition and mobility 2004-2015- Teacher follow up survey. Institute of Education and sciences (IES) Us. Department of Education NCEs 2007-307

National Commission on Teaching and Americas Future, (1997). Doing what matters most, Investing in quality teaching. New York.

National Education Collaboration Trust. (2014). South African Education Portal. Retrieved on $27 / 02 / 2014$ at $2.30 \mathrm{pm}$.

Ndalo, C.K. (2009). Road books to Leadership in Nyanza Province, Education watch. p. 55. 
Ng'ang'a, A.W. (1989). A study of graduate dissatisfaction and satisfaction. A case study of post graduate Diploma in Education Project. Kenyatta University of Kenya. Master Thesis, Lakeland Thunder Bay, ON.

Ngare, N.(2008). Six hundred teachers quit classroom for better jobs, May $5^{\text {th }}$,The Daily Nation. Nairobi. Nation Media group .pg 8.

Nhundu T.J. (1994) Facet and overall satisfaction with teaching and employment condition of teachers in Zimbabwe. Zimbabwe journal of education and research,6:152-194

North Central Education Laborator Policy issues June 2001, issue teacher retention strategies in the mid west.http//www.ncref.org/policy/pubs/p/june 2001,htm(2007) May $24^{\text {th }}$

Nwankwo, J. (1982). Educational Administration. Theory and Practice, New Delhi. Vikas Publishing House.

Nzuvu, J. (2005). Effectiveness of BOG in Recruitment of teachers in public secondary schools in Taita Taveta District. Unpublished masters of education thesis. University of Nairobi.

Obiero, D. (2009, January $\left.5^{\text {th }}\right)$. Sacking threat fail to deter pay protest. Daily Nation. Nation Media Group. pg 3

OIRERE, M. K. (2005). Perceived effectiveness of decentralized teacher recruitment in primary schools in Gucha district. Unpublished Masters Thesis. Nairobi University.

Okumbe, J.A. (1999). Educational Management. Theory and practice. Nairobi. University press. Nairobi.

Okumbe. J.A. (2001). Human resource management; Educational perspective. Nairobi Educational Design Research Bureau .

Organization for Economic Corporation and Development (OECD). (2002). The teaching workforce, columns and policy challenges: Education policy analysis.

OSO,W.Y \& Onen.D (2011) A general guide to writing research proposal and report a hard book for beginning research(Revised edition). The Jomo Kenyatta foundation in Kenya Nairobi

OSO,W.Y \& Onen,D. (2009). Writing research proposal and report namb sitima press

Otiende, J.E., Wamahinn, S.P., \& Karagan, S. (1992). Education development in Kenya; A Historical perspective. Nairobi, Oxford University Press.

Otieno,A.O. \$ Ofulla,A (2009) Drug abuse in Kisumu Town, Western Kenya. An African Journey of food, Argentina, Northern and Development vol 9(3) 846-858

Otieno,C.( 2007) "countries cannot get qualified teachers ".East Africa Standard. Nairobi Standard group.

Otsialo, M. (2014, Thursday November 27 $\left.7^{\text {th }}\right)$. Don't abandon us, County boss appeal to civil servants. Daily Nation, Nation Media Group. , pg 5

Ouma,W.(2014). Candidates start sitting their papers tomorrow. Daily Nation October $20^{\text {th }}$ Nation Media Group. pg8.

Peril and Promise (2000). Higher education in Developing Countries Task force on Higher education and society. Washington DC.

Pillay, R. (2001). Top teachers head hunted by UK agencies. Malli Guacheri, Feb $9^{\text {th }}$.

Polit, D.F., Beck, C.T. \& Hungler, B.P. (2001). Essential of Nursing and Research: Method appraisal and utilization. ( $\left.5^{\text {th }} \mathrm{Ed}\right)$ Philadelphia.

Price, J. (1997). The study of turnover America, AI: Iowa State University Press.

Public Agenda. (2009). Retaining teacher talent. Survey of teachers. New York. Retrieved feb $8^{\text {th }}$ 2010 from http:///www.learningtp.

Punch,F.K. (2010). Introduction to social Research. Quantitative and Qualitative Approaches(2 $2^{\text {nd }}$ Edition) New Del. Sage publications ltd.

Punch,K. (2005). Introduction to social Research, quantitative and qualitative approaches. London Sage.

QING Li \& xin maj (2010) Analysis of effects of computer Technology on school students, mathematic learning Ed. Psychology per 215-244. 
Quez (2008). Careers in motion: A longitudinal study of Role changing among early career urban education: Teachers college Record Vol. 110 November, 2008 p. 218250.

Raburu, P.A. (2011). Women Academics Career in Kenya. Published PHD Thesis Lancaster University. UK.

Raburu, P.A. (2015). Motivation of Women Academics and Balancing family and Career. Journal of Education and Social Research. Vol. 5: 359-370.

R.O.K. (1999). Totally integrated quality education and training: Nairobi, Government Printer.

R.O.K. (2003). Report on sector review and development. Nairobi, Government Printer.

Rauniyar, G.(2009). Impact of Water Supply and Sanitation.Punjab.graniyar@ad b.org. Retrieved $16 / 10 / 2009$.

Rebore,W.R.(1991). Personnel Administration in Education Management Approach. New Jersey; Prentice Hall.

Reed, D., Reuben, K.S. \& Barbour, E. (2006). Retention of New Teacher in California, San Francisco. CA; Public Policy Institute of California.

Reininger, M. (2006). Teacher Isolation, preference and the implication for schools with different student population. Working paper.

Republic of Kenya (1980). Education Act. Nairobi. Government press.

Republic of Kenya (1999). Totally integrated quality of education and training. Government Printer. Nairobi.

Ripley, (2010). What makes a great teacher? The Atlantic. Retrieved Feb $8^{\text {th }} 2010$ from http://www.atalantic.com/doc. good teaching.

Roger, B., Winston, J.R., Don, G., \& Greammer, J. (1997). Improving staffing practice in students affairs. Bass Publishers. San Francisco.

Rothman,E. P. (1981). Troubled teachers (New York).

Rumberger, R. (1985). The shortage of mathematics and science teachers A review of the evidence, educational evaluation and policy analysis 7(4):955-969.

Sang, A. (2005). Teachers recruitment in Kenya: A study of urban secondary schools in Uasin Gishu District, Kenya. Unpublished Masters of Philosophy thesis. Moi University.

Sari.H. (2004). An analysis of Born and sub satisfaction among Turkish special school head teacher and teachers and the factor affecting bur sorts and joy satisfaction. Educational studies 30:291270. Abstract returned $3^{\text {rd }}$ may 2005 from EBSCOHOST database.

Sasikumar, V. (2013). The Education Systems in India.

Scafidi, B., Stine brickner, J. \& Sjoquist, D. L. (2003). The Relationship between school characteristics and teacher mobility. Working paper. Atlanta GA, Georgia State University.

Schonfield,T.S(1990)Psychological distress in a sample of teachers. The journal of psychology. 124:34-338.

School Staffing (England). (2001). www.opsi.gov.uk.si

Sergent, T.C. (2003). Who will teach the poor and remote? Teacher Distribution and Job satisfaction in rural Chimna. Unpublished Masters of Education thesis. University of Pennsylvania.

Sergiovanni, T. J. \& Carve, F.D. (2003). The New School executive; A theory of Administration. New York; Harper and Row publisher inc.

Sergiovanni, T.J. (2009). Leadership What is in it for Schools? Department of education. Retrieved from http://www.slideshare.net/charlescorn/serg.

Shann Tyson, Alfred York (2002). Essential of human resource management. $4^{\text {th }}$ edition Butterworth /Heinemann Oxford, Australia.

Sifuna, D.N. \& Otiende, J.E. (2006). An Introductory: History of Education. Nairobi. University of Nairobi. Government Press.

Silverman, D.(2001). Interpreting qualitative data London, Sage

Smith, J, M. \& Ingersoll, R.M. (2003). Does Teacher Mentoring matter? Unpublished Manuscript.

Smith, T. \& Ingersoll, R.M. (2004). What are the effects of Induction and Mentoring on beginning teacher turnover? American Educational Research Journal 41 (3) 685-714. 
Effects of Staffing Policies on Public Secondary School Teachers' Distribution in Homa-Bay County, Kenya

Sogomo, K.C. (1993). Job satisfaction of secondary school principals in Rift-valley Province of Kenya. Masters Thesis, Lakeland University -Thunder Bay ON.

Syneider, T., Hoffman, C. \& Geddes, C. (1997). The Digest of Education Statistics, Washington DC: National Centre for Educational Statistics.

Teachers Service Commission (2002). Operational Manual on Teacher management. Jomo Kenyatta Foundation.

Teaching Service Commission. (2009). End of year report. Mbamande MOE/TSC.

Teddlie, C. \& Reynolds, D. (2000). The international Handbook of School effectiveness Research. London. Falmer Press.

Theresia, T. (2014, 19 ${ }^{\text {th }}$ Sept ). The Namibia Staff Shortage and Effect New Curriculum.

Teacher Shortage crisis affects half of South Africa school.

Teacher Migration in South Africa (2011).

Texas centre for educational Research (2000) The cost of teacher turnover. Austine,TX:Texas,state Board for teacher certification(SBEC)

Thorton, J. \& Ryan. (2006). The conflict of religion in America's public schools, New York, Oxford University Press.

TSC in danger of devolving corruption to the counties. Wednesday January $1^{\text {st }}$ 2014. The Standard. Standard Media Group.

TSC (2005). Code of Regulation for Principals. Government Press.

TSC asked to release hiring letters and post New teachers. Thursday December $20^{\text {th }}, 2013$.Nation Correspondence. Nation Media Group.

UNESCO. (2005). Special intergovernmental conference recommendation concerning the status of Teachers, 5 October 1996 Paris. UNECSO. Available http://unescodoc.unesco.org.

UNESCO. 2003). Education For All news. Issue. Nairobi. UNESCO.

Urabanski, A. \& Connel, O. (2003). Transforming the profession of teaching. It starts at the beginning. Retrieved May $9^{\text {th }} 2006$ from http:///www.ncthf.org/article/?g=usc=3ssc.

Urch, G.E.F. (1968). The Africanization of curriculum in Kenya. Michigan University of Michigan; Competence Education Dissertation series.

US Bureau of Census (1998). Statistical Abstract (117 th Edition). Washington DC: Department of Commerce.

Volunteer Service Overseas (2002). Teachers speaks out. A policy research report on teachers motivation and perceptions of their profession in the Gambia VSO. UK.

Wachira, M. (2014, November $\left.27^{\text {th }}\right)$. Citizen must play a role to secure country. Daily Nation, Nairobi. Nation Media Group.

Wengrof.T. (2001) Quantitative research intensifying London, Sage 